The Geological Society of America

Special Paper 471

2010

\title{
Distinguishing damages from two earthquakes-Archaeoseismology of a Crusader castle (Al-Marqab citadel, Syria)
}

\author{
Miklós Kázmér* \\ Department of Palaeontology, Eötvös University, P.O. Box 120, H-1518 Budapest, Hungary \\ Balázs Major* \\ Department of Arabic and Islamic Studies, Péter Pázmány Catholic University, Egyetem utca 1, H-2087 Piliscsaba, Hungary
}

\begin{abstract}
Damages from two major earthquakes are identified in medieval Al-Marqab citadel (Latin: Margat) in coastal Syria. Built by the Order of St. John (Hospitallers) in the twelfth-thirteenth centuries, the hilltop fortification has masonry walls made with and without mortar, using the opus caementum technology (Roman concrete). V-shaped and U-shaped failures, single-corner and symmetrical corner collapses, and in-plane shifts of ashlar masonry walls are identified and dated by historical and archaeological methods. The azimuth of displacement is NE-SW for the older damages of the Crusader period (A.D. 1170-1285), possibly related to the A.D. 1202 earthquake. A later, NW-SE displacement occurred during the Muslim period (post1285). The 1202 earthquake produced at least VIII intensity on the MSK scale at AlMarqab, which is higher than previously considered.
\end{abstract}

\section{INTRODUCTION}

After a few decades of hesitating progress, archaeoseismology is becoming a quantitative science using a rigorous methodology. At the moment, it is still uncertain whether seismic traces in destruction layers and buildings can be translated into earthquake parameters such as intensity, peak ground acceleration, magnitude, distance to epicenter, etc. (Sintubin et al., 2008). This paper is intended to be a small step toward this quantification by offering a method to distinguish among traces of successive earthquakes, to establish a temporal succession, and to identify vibration directions. However, one should not forget that the latter are not necessarily straightforward indicators of epicenter locations (Hinzen, 2008, 2009).
In the past few decades, spectacular features of failure of various archaeological monuments in the Eastern Mediterranean and Near East have attracted interpretations of earthquakes in general, especially among archaeologists (Kilian, 1980). Cautionary words by seismologists, (e.g., Ambraseys, 2005a, 2006) warned that failures attributed to earthquakes are often due to poor foundation practices, landslides, and changes in groundwater level. In the meantime, a stream of publications by geologists appeared, describing major fault-related deformation of walls and buildings. Since displacement along geological faults is an unequivocal sign of earthquakes, these papers provided a solid foundation for proper interpretation of earthquake-related damages (Hancock and Altunel, 1997; Ellenblum et al., 1998; Galli and Galadini, 2001; Sintubin et al., 2003; Altunel et al., 2003;

\footnotetext{
*E-mails: Kázmér_mkazmer@gmail.com; Major_balazs.major.hu@gmail.com.

Kázmér, M., and Major, B., 2010, Distinguishing damages from two earthquakes-Archaeoseismology of a Crusader castle (Al-Marqab citadel, Syria), in Sintubin, M., Stewart, I.S., Niemi, T.M., and Altunel, E., eds., Ancient Earthquakes: Geological Society of America Special Paper 471, p. 185-198, doi: 10.1130/2010.2471(16). For permission to copy, contact editing@ geosociety.org. @ 2010 The Geological Society of America. All rights reserved.
} 
Galli et al., 2008; Karakhanian et al., 2008a). Where the faults responsible for displacement are excavated and corresponding shifted beds are dated (e.g., Meghraoui et al., 2003; Reicherter et al., 2003), these features are among the best evidences for earthquake-related damages.

Other deformations as seen on buildings, like broken window and door frames, dropped keystones, displaced and/or rotated ashlars of masonry walls (e.g., Nikonov, 1988; Korjenkov and Mazor, 1999, 2003; Akyüz and Altunel, 2001; Altunel et al., 2003; Sintubin et al., 2003; Caputo and Helly, 2005; Similox-Tohon et al., 2006, 2007; Al-Tarazi and Korjenkov, 2007; Karakhanian et al., 2008a, 2008b; Marco, 2008), and spectacular disarrangement among drums of columns in Greek and Roman temples (e.g., Stiros, 1996; Stiros et al., 2000; Bottari, 2005), crosscutting breaks in walls, and twisted walls (e.g., Kamh et al., 2008; Nur and Burgess, 2008) have often invited interpretation as earthquake damages. Theoretical background of these interpretations is often missing. Alternative explanations have been sought for decades: foundations problems and poor construction practices have been considered, while precise recording of observations has been emphasized for the benefit of subsequent researchers (e.g., Karcz and Kafri, 1978). Seismic-induced landslide damage to buildings is also a problem (Wechsler et al., 2009).

Here, we attempt to follow the example of Korjenkov and Mazor (1999, 2003) using kinematic indicators borrowed from structural geology in the interpretation process. After a preliminary report on earthquake-induced damages at Al-Marqab (Kázmér, 2008), we proceed with the quantitative characterization and identification of past earthquakes using archaeoseismology. This article is a small step toward a rigorous and transparent methodology for archaeoseismology (Stiros, 1996; Galadini et al., 2006; Sintubin and Stewart, 2008).

\section{AL-MARQAB CITADEL}

Al-Marqab citadel (Arabic: Qal'at Al-Marqab; medieval Latin: Margat), in the coastal region of the Syria, is one of the largest and most important medieval castles of the Levant (Figs. 1-2). The site is perched on top of a 350-m-high volcanic mountain, $\sim 2 \mathrm{~km}$ inland from the coast, overlooking the town of Banyas and guarding the coastal route. It also has commanding views of the fertile plains toward Latakia in the northeast, and it dominates the Jabal Ansariyya ranges to the east.

\section{History}

The first castle of the site is reported to have been built by the local inhabitants in H. 454 (A.D. 1062-1063). After a brief period of Byzantine occupation starting around 1104, it was taken by the Franks (Crusaders) from the local tribes in 11171118. The castle seems to have reverted to as-yet-unknown Muslim hands in the 1130s during the civil war in Antiochia. It was recaptured by Renaud II Mazoir in 1140, and then became the seat of the Mazoir family (Deschamps, 1973, p. 260-261). The Mazoirs were one of the highest-ranking baronial families in the Crusader principality of Antioch and were responsible for building most of the earliest surviving structures in the castle. In early February 1187, the Mazoirs transferred Al-Marqab and all their

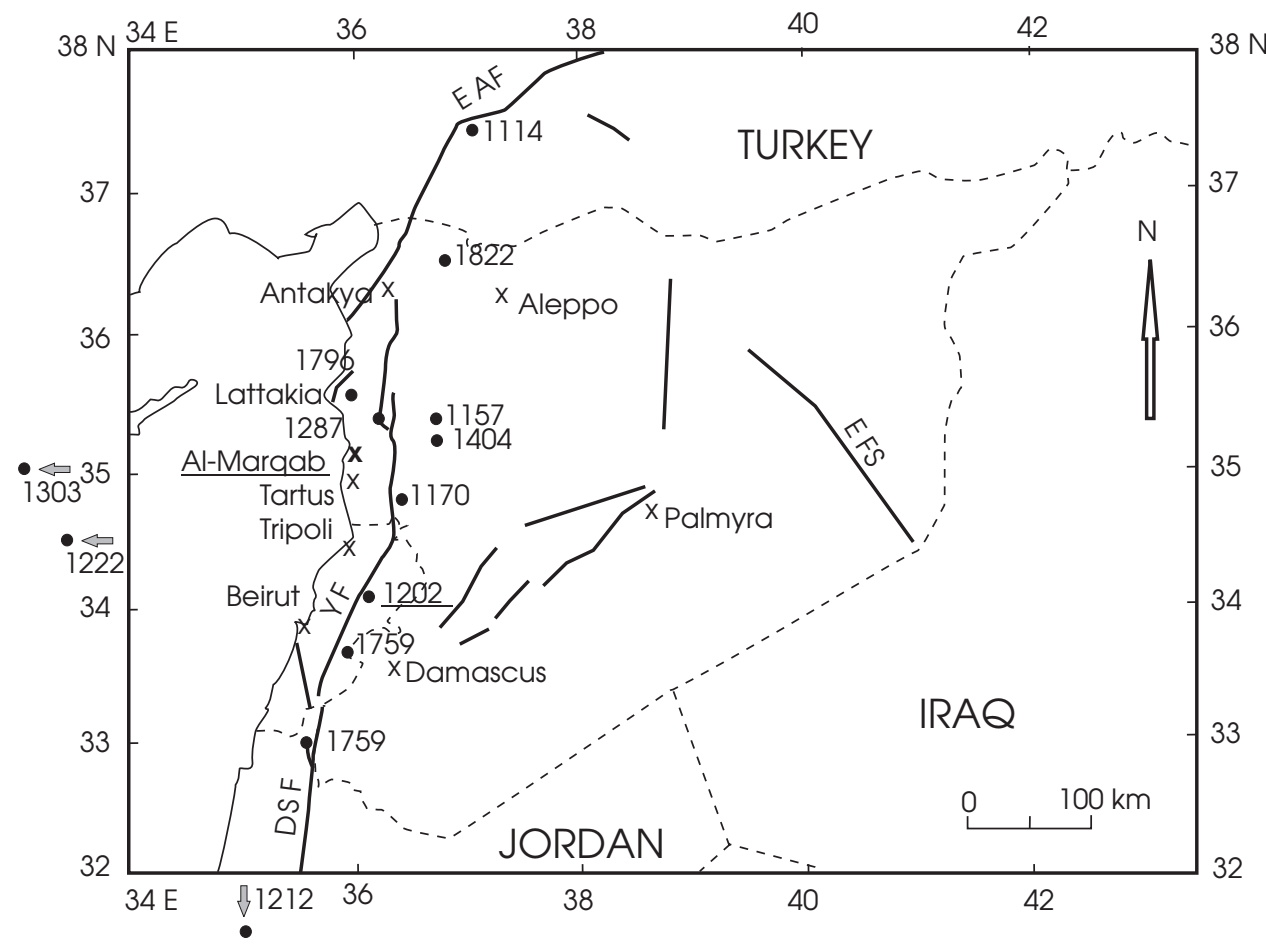

Figure 1. Location of Al-Marqab (Margat) citadel in coastal Syria. Major historical earthquakes are centered along left-lateral strike-slip faults ranging from the Dead Sea fault in the south to the East Anatolian fault in the north (modified after Sbeinati et al., 2005). Epicenter of the A.D. 1202 earthquake, extensively discussed in the text, is underlined. Epicenters of the events of 1212, 1222, and 1303 earthquakes are out of the map in Jordan, Cyprus, and Crete, respectively. DSF-Dead Sea fault system, YFYammouneh fault, EAF-East Anatolian fault system. EFS-Euphrates fault system. Epicenter locations are from Ambraseys (2009, electronic supplement). See also Table 1. 


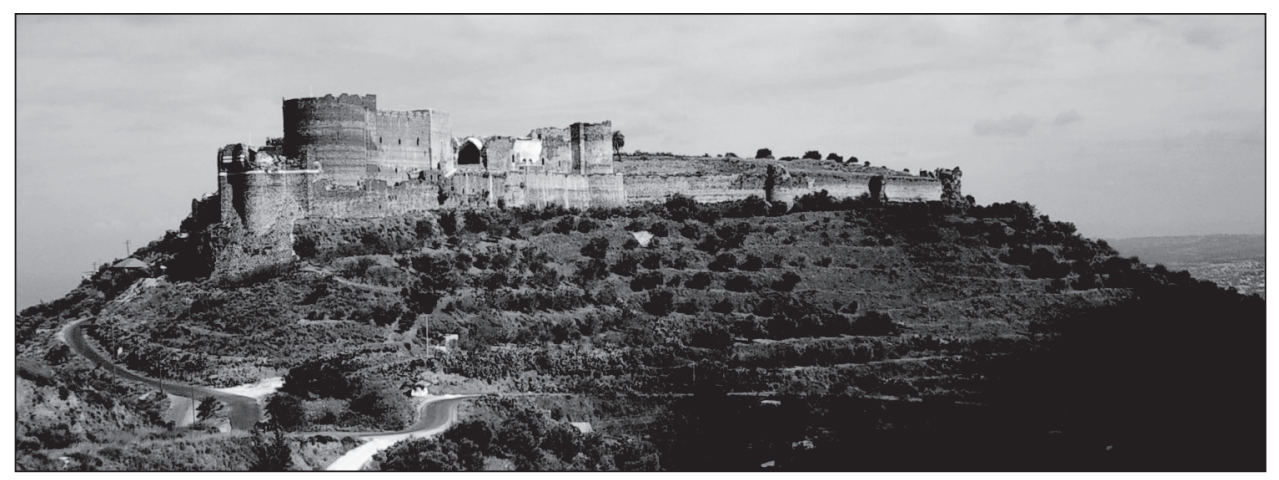

Figure 2. Al-Marqab citadel, as seen by attacking enemy from the south, was mostly built by the crusading Order of St. John (Hospitallers) in the late twelfth century. The hilltop plateau, $350 \mathrm{~m}$ above sea level, is vesicular basalt lava of Pliocene age, exposed below the highest towers. Terraces of olive gardens carved in weathered basaltic strata cover the slopes. Banyas city and the Mediterranean Sea are seen in the background on the right.

landed properties to the Order of St. John (Hospitallers) due to unbearable maintenance costs related to warfare and damaging earthquakes (Burgtorf, 2007). The Hospitallers turned the castle a military, judicial, and administrative center of the region.

Given the fact that Al-Marqab became the central castle of one of the most influential organizations of the age, it is not surprising that the Hospitaller period was characterized by largescale construction programs that resulted in the erection of most of the surviving buildings seen on the mountain top. The castle was put to the test several times by besieging armies. It was besieged by an army from Aleppo in 1204-1205, and again in 1231. Banyas and the lands around the castle were destroyed by the Aleppines. Attempts on the Muslim side to take the castle twice, once in 1269-1270, and subsequently in 1281 and 1282, ended in failure. Al-Marqab was finally taken by the Sultan Qalawun on 25 May 1285 after a relatively short siege of $5 \mathrm{wk}$. The sultan agreed to the peace offer of the garrison to save the castle from further damage, and the destructions caused by the siege were repaired immediately (Ibn-Abdazzahir, 1946). After the complete expulsion of the Crusaders, the castle started losing its importance, and its diminishing role in the Mamluk (1250-1517) and Ottoman periods (1517-1917) is reflected in the reduced scale of later building activities. For a lively description of the castle and the function of various buildings, see Kennedy (1994, p. 163-179). For additional details concerning the history of AlMarqab, the reader is referred to Major et al. (2010).

\section{Seismicity and Large Earthquakes}

Besides the relatively scarce military activity, earthquakes were another considerable factor in the building history of the castle (Table 1; Fig. 1). The major earthquakes of 1114, 1157, and 1170 are suspected to have caused considerable damage to the pre-Hospitaller castle. The earthquake of 20 May 1202, one of the strongest in the history of the region, did severe damage to the castle, but left it defensible for the time being. We do not have any mention of whether other earthquakes of the thirteenth and fourteenth centuries in northern Syria affected the fabric of the castle $(1212,1222,1236,1287,1303,1339)$, but the earthquake of 20 February 1404 certainly did bring down a considerable part of the castle (Sbeinati et al., 2005, p. 392). Amongst the later earthquakes, the ones of 1752 and 1759 are very likely to have affected Al-Marqab, and the ones of 26 April 1796 and 13 August 1822 are explicitly described to have caused serious damage to the castle (Sbeinati et al., 2005, p. 379-398) (Table 1; Fig. 1).

The medieval building complex of Al-Marqab occupies the whole mountain top (Figs. 2-3), covering 5.7 ha, and is made up of two basic units. In the southern part of the mountain stands the concentric citadel, covering an area of 0.9 ha, while the rest of the mountain plateau is occupied by a huge suburb, which is also enclosed in a double line of defensive walls. Some parts of this suburb were inhabited until 1959. In the first phase of the research program, the work of the Syro-Hungarian Archaeological Mission (SHAM) focused primarily on the citadel area.

Objectives of the Syrian-Hungarian Archaeological Mission are archaeological excavation, architectural survey, and photogrammetry of Al-Marqab citadel; conservation and restoration of unique medieval frescoes and artifacts; scientific (geological, geophysical, archaeozoological, archaeobotanical) investigations; study of the medieval technologies; exploration and reconstruction to working use of the medieval water-collection and sewage disposal system with the aim of donating the water collected to the neighboring villages; folklore studies to document and revitalize the traditional Syrian village life and houses in the suburb; and landscape archaeology to reconstruct the medieval rural settlement pattern and provide training opportunities for students from the east and the west. These activities prepare AlMarqab for nomination as United Nations Educational, Scientific, and Cultural Organization World Heritage Site.

\section{METHODS}

A plan of architectural structures has been provided by a previous geodetic survey carried out within the framework of EuroMED project. This is continuously being upgraded by SHAM members as archaeological excavations proceed (Fig. 3, 5 , and 8-10). During the autumn field season of 2008, we identified and surveyed various damages and failures visible on buildings and walls. Some of those attributable to earthquakes are described, illustrated, and explained here. Boundaries of displaced or collapsed portions of ruptured walls were measured by tape, compass, and clinometer: measurements of azimuth/strike 


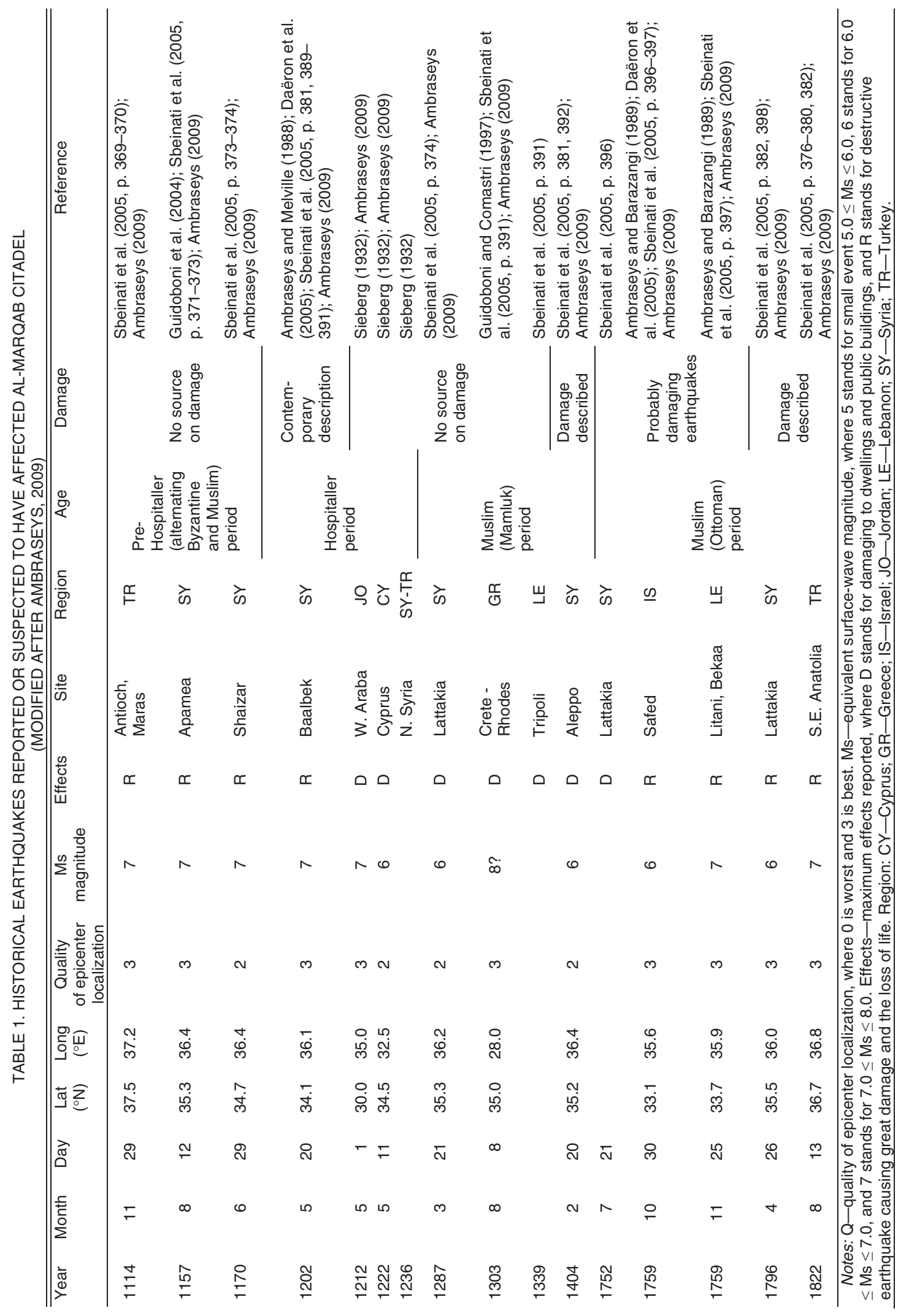




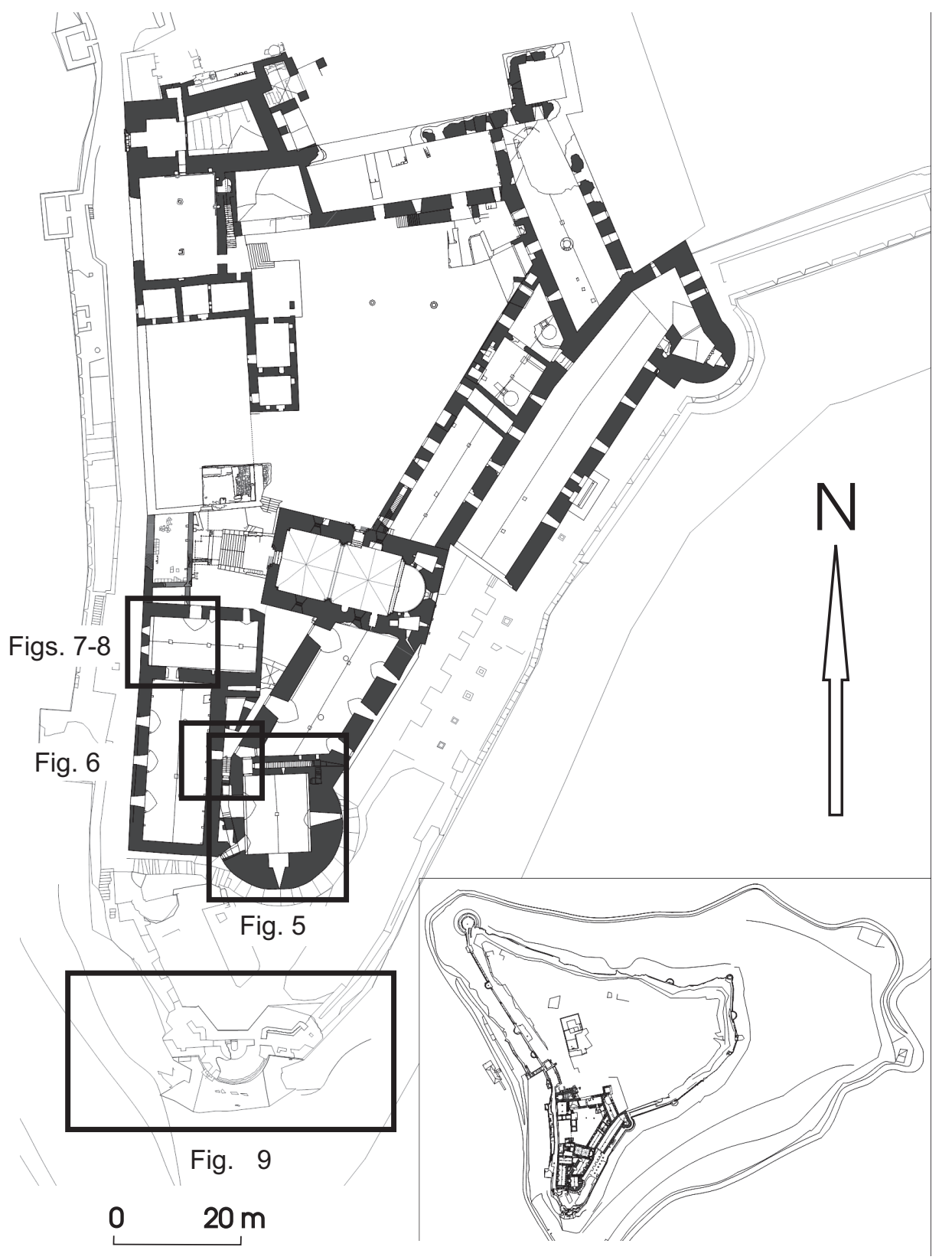

Figure 3. Plan of the southern portion of Al-Marqab citadel. Heavy lines denote buildings with aboveground walls. Light lines are circumferential walls and excavated foundations of buildings. Inset displays the location of the heavily fortified southern part and the much larger northern suburb, surrounded by weaker walls, totaling 5.7 ha together. The external double line is the modern asphalt road surrounding the hilltop.

and dip of bounding planes allow the description of failure orientation in space. Similar orientations of the stress field are inferred to form failure groups, where each stress field system occurred only once. Archaeological dating provides the ages of particular failures and related stress fields, which are correlated to past earthquakes using the seismicity catalogue (Fig. 1; Table 1).

Direct and indirect archaeological evidences provide temporal constraints on failures. Direct evidence is where we can document a failure of a building of known age: the failure is certainly younger than the construction date (terminus post quem datum). Indirect evidence for dating a failure is provided where an adjacent building of known construction age does not bear the same damage (terminus ante quem datum). Direct evidence is hard and reliable; indirect evidence is soft and is prone to several errors, e.g., the adjacent building stands on different soil, was erected by different technology, has different structure, and-ultimately-is characterized by different vibration characteristics.

\section{RESULTS}

\section{Masonry Components and Types}

Most walls of Al-Marqab, both Crusader and Muslim, are one of two types: either stone masonry or opus caementitium, i.e., "Roman concrete" (Lamprecht, 2001) or "ancient concrete" (Ferretti and Bažant, 2006). Stone masonry is characterized by 
dressed stones, carved rectangular and of standard size, with or without mortar, always without metal anchors. Arches, door, and window ledges, box machicolations, and some wall heads have been constructed this way.

"Roman concrete" or "ancient concrete" is a mixture of sand, lime, and added stone material and is very similar to modern concrete in appearance. Invented by the Romans, the technique survived well into the Middle Ages. Opus caementitium is often combined with traditional masonry, where an outer, visible layer of variously dressed blocks was erected with mortar. This external, regular masonry work served during construction as a mold for casting the core. Poured material served for the inner, invisible parts of the wall (Ferretti and Bažant, 2006; Mistler et al., 2006). Masonry both served aesthetic demands and provided a hard, protective layer to counter weather effects and enemy attacks. This layer often served as framework during concrete pouring only, having no supporting function when concrete hardened (Fig. 4). Walls and vaults of variable thickness, from a few tenths of a meter up to $5 \mathrm{~m}$ thickness, were constructed this way.

This multilayer construction technology made walls of AlMarqab castle extremely durable, even without reinforcement. For assessment of earthquake damages, the external masonry is treated as consisting of discrete blocks, while the concrete wall behaves as a cohesive block. For modeling purposes, this kind of wall is treated as poor Portland cement concrete (Ferretti and Bažant, 2006). While this type of wall may deteriorate through the centuries due to creep and fatigue (Anzani et al., 1995, 2009), we can be sure that this was not the case just a few decades after construction.

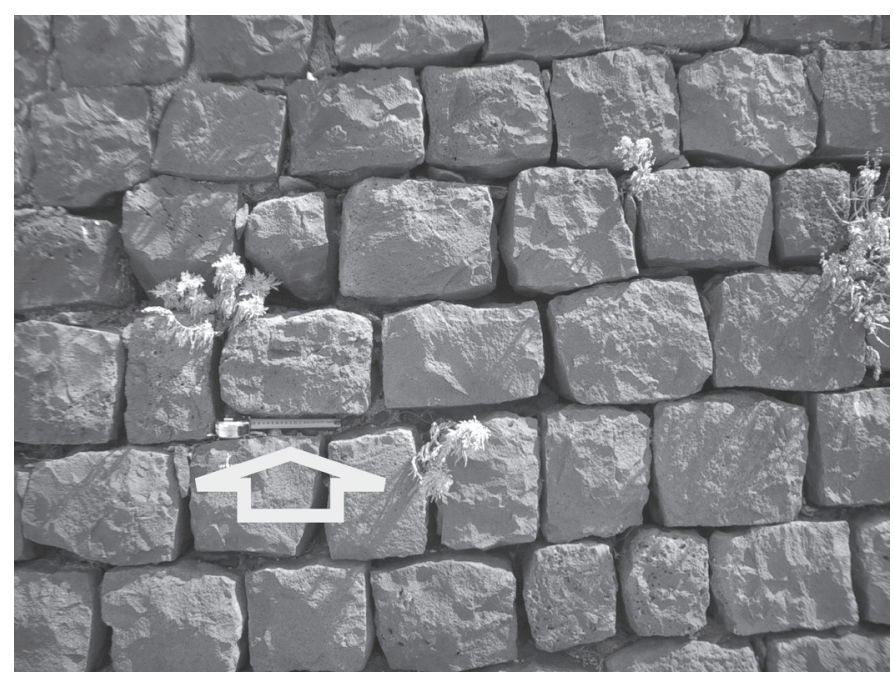

Figure 4. Ashlars in the western, windward wall of the donjon are seemingly unsupported. However, their rear side is firmly embedded in Roman concrete, the cementing material of the several-meter-thick wall. Laid initially with mortar, westerly winds and rain have removed much of it throughout eight centuries. Arrow: measuring tape for scale, $20 \mathrm{~cm}$ long.

\section{FAILURES}

\section{V-Shaped Failure}

There is a spectacular V-shaped extrusion on the donjon, the main tower of the citadel of $5 \mathrm{~m}$ height and $5 \mathrm{~m}$ width (Fig. 5). Similar features occur elsewhere in the castle. It seems that if failure were to progress, we would see a wedge-shaped block missing from the wall of the donjon.

The V-shaped block is shifted toward the SW by $\sim 20 \mathrm{~cm}$. No trace of it can be seen within the donjon. Bounding surfaces are joined before reaching the hall inside.

\section{Single Corner Collapse}

Adjoining, possible perpendicular walls have collapsed at their joining. Collapse occurs where both walls are free-standing, i.e., unconfined at least to one side. This partial collapse produces an uneven oblique surface, cutting both walls at an angle (Fig. 6). Although of irregular shape, the pattern of collapse is comparable to a failure plane that can be interpreted as a normal fault. The smoothed surface of the failure is considered the fault plane, where the two directions necessary for geological characterization, strike and dip, can be measured and/or calculated. Because we do not have any evidence for the displacement direction of the hanging wall (fallen fragments have been cleared centuries ago), we assume dip slip.

Similar failures are illustrated by Galadini et al. (2006, his Fig. 2a), Penazzi et al. (2001, their Fig. 1), and Tomaževič and Lutman (2007, their Fig. 7).

\section{Symmetrical Corner Collapse}

Room M3 sits on top of the vault of the kitchen. It is the sole remnant of a previous, larger cluster of rooms, which might have served as an independent kitchen. Walls that are 66 to $104 \mathrm{~cm}$ wide bear a barrel vault. Diagonally opposite corners have suffered symmetrical damages (Figs. 7-8). Fractures that are concave outward have developed. The NE corner collapsed in full, destroying a segment of the vault and portions of the adjacent wall (Fig. 7A). The concave fault developed in the SW corner as well, but only part of the vault collapsed: there is a $2 \times 1 \mathrm{~m}$ hole in the top of the vault, connected by an arcuate fracture-a wouldbe failure scar-to the still-intact adjacent walls (Fig. 7B).

\section{U-Shaped Gap}

The top of the southern corner tower of the outer enceinte, the outer ring of walls of the Mamluk-built structure, bears a downward-concave failure. Both thin and thick portions of the tower have failed (Fig. 9).

A wider than deep, downward-concave failure mode is illustrated by spectacular examples from Pompeii by Martini (1996, his scoop-like failure). It was produced by shaking of relatively 

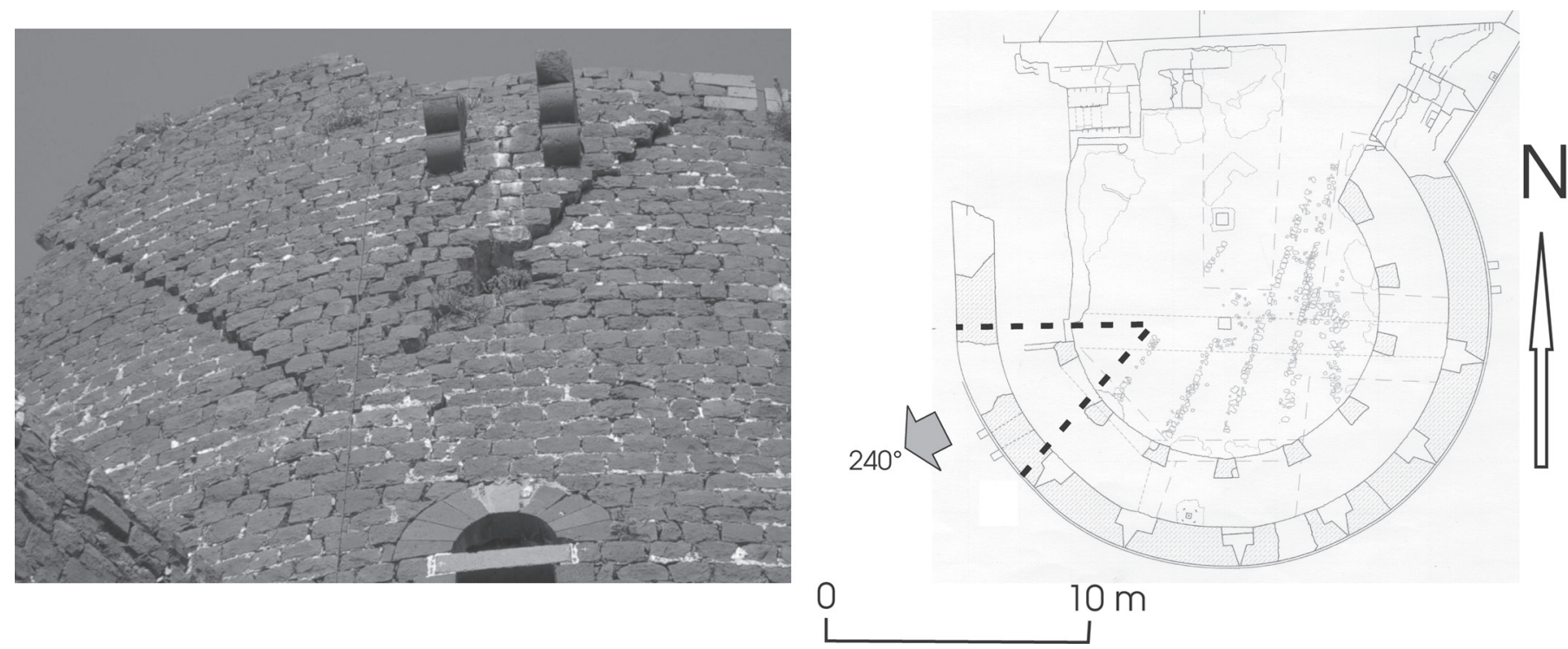

Figure 5. Left: A wedge-shaped block of donjon masonry wall moved toward $240^{\circ}$ azimuth by $\sim 20 \mathrm{~cm}$. Right: Dashed line on archaeological plan of the top of donjon indicates estimated shape of displaced wedge. Gray arrow denotes direction of displacement.

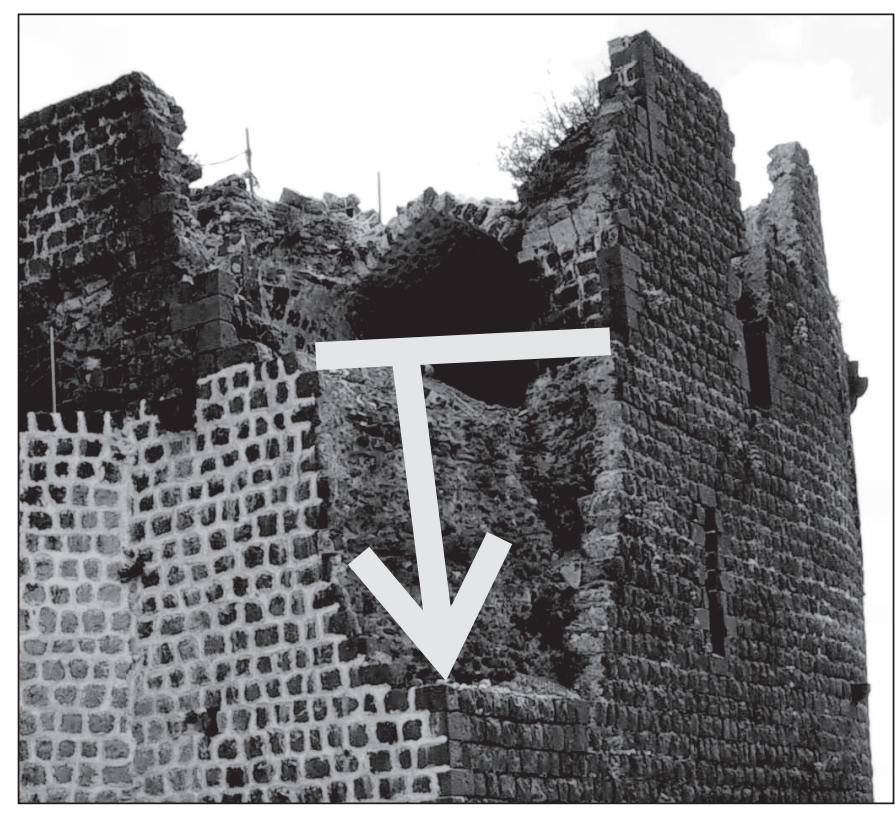

Figure 6. Failed corner of perpendicular walls at NW corner of the donjon. Approximated by a normal fault dipping $\sim 50^{\circ}$ to $284^{\circ} \mathrm{NW}$ direction. Failure is $\sim 3 \mathrm{~m}$ wide at horizontal line.

thin walls (Lourenço et al., 2007, their Fig. 5), semiconfined at both ends by walls adjoining at an angle, often perpendicularly. Similar failures have been described by Similox-Tohon et al. (2006, their Fig. 5d; 2007, their Fig. 5d) and Sintubin and Stewart (2008, their Fig. 12b).

\section{Dislodged Building Blocks}

A large variety of shifted and rotated building blocks (ashlars) are seen at Al-Marqab. A shift within the plane of the wall is spectacularly shown in Figure 10. Heavily protected stone boxes extrude from the top of walls. Open bottoms allowed defenders to pour hot water, oil, or burning tar on attackers climbing the walls.

Box machicolations and adjacent walls on top of the southern Mamluk tower suffered in-plane extension of several tenths of a meter, and open spaces up to $10 \mathrm{~cm}$ wide formed between adjoining blocks during ground shaking. Although an indirect observation, this type of damage is confidently assigned to earthquakes, even by the otherwise cautious Ambraseys (2006, p. 1010). Similar open joints are described by Sintubin et al. (2003, their Fig. 5a) and Marco (2008, his Fig. 2F), and have been reproduced by vibration experiments (Vasconcelos et al., 2006, their Fig. 7).

There are many other kinds of damages observed in AlMarqab: dropped keystones, in-plane and out-of-plane failures of walls, twisted walls, rotated blocks, extruded blocks, etc., which will be treated separately.

\section{Subsoil}

The buildings and walls of Al-Marqab have been erected on the solid subsoil of a several-meter-thick layer of compact Pliocene basalt (Fig. 11). This rock is not prone to liquefaction, even under major earthquakes, and neither is it affected by compaction under changing groundwater level (Ambraseys, 2006). The latter is $\sim 50 \mathrm{~m}$ below the citadel, as shown by the location of the public bath on the western hillside. 

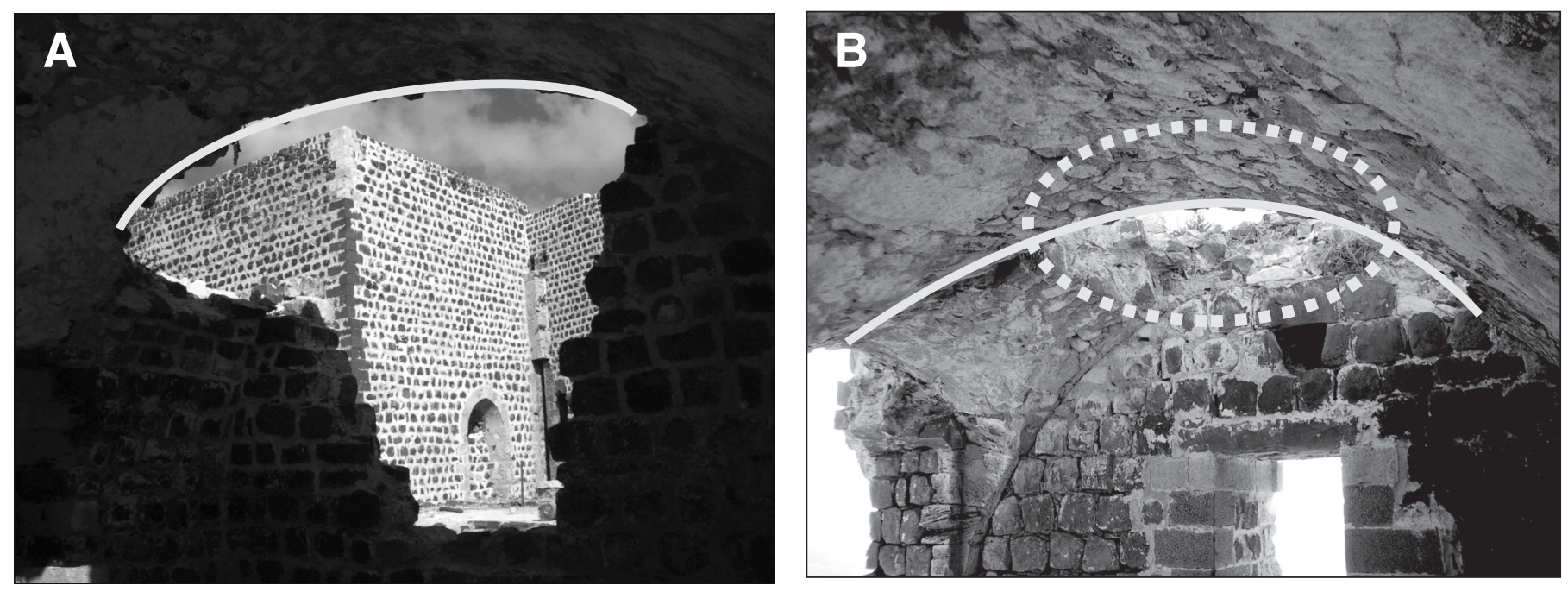

Figure 7. Room M3, as seen from inside, bearing symmetrically arranged damages to opposite corners due to a NE-SW-oriented vibration. (A) Collapsed NE corner of room M3, concave fracture (light curve) facing $50^{\circ} \mathrm{NE}$. Failure is $4 \mathrm{~m}$ wide. (B) Partially damaged SW corner of room M3, concave fracture (light curve of $4.5 \mathrm{~m}$ span) facing $240^{\circ} \mathrm{SW}$. Fallen portion of damaged vault is encircled by dashed line.

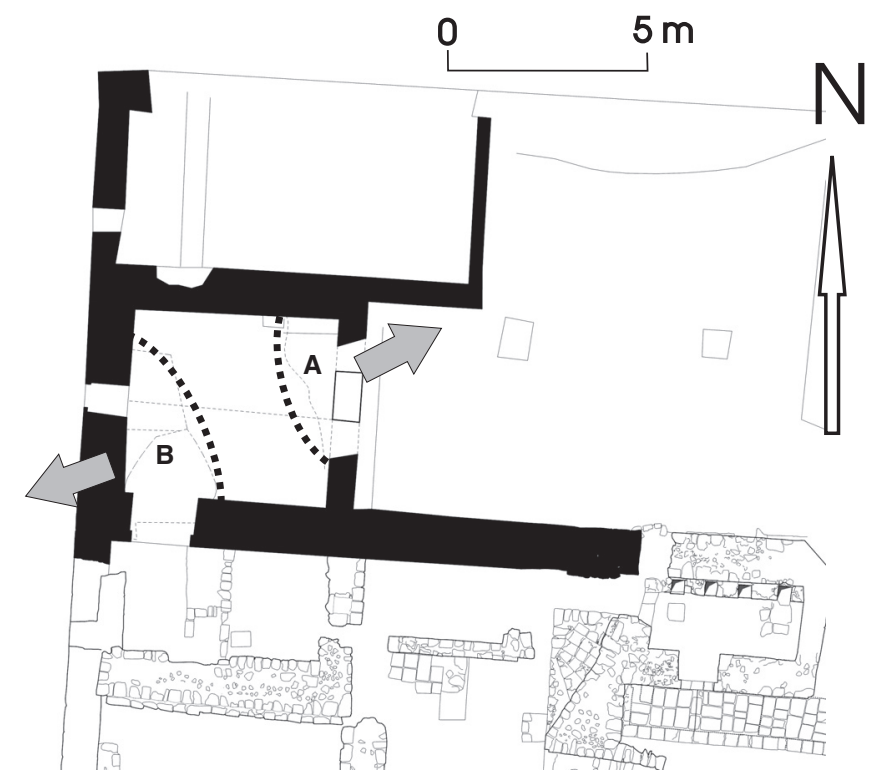

Figure 8. Plan of room M3. Outline of symmetrical failures is indicated by dotted lines. Letters A and B correspond to failures shown on Figure 7. Arrows indicate $50^{\circ}-240^{\circ}$ extension direction, similar to the azimuth of the V-shaped failure of the donjon.
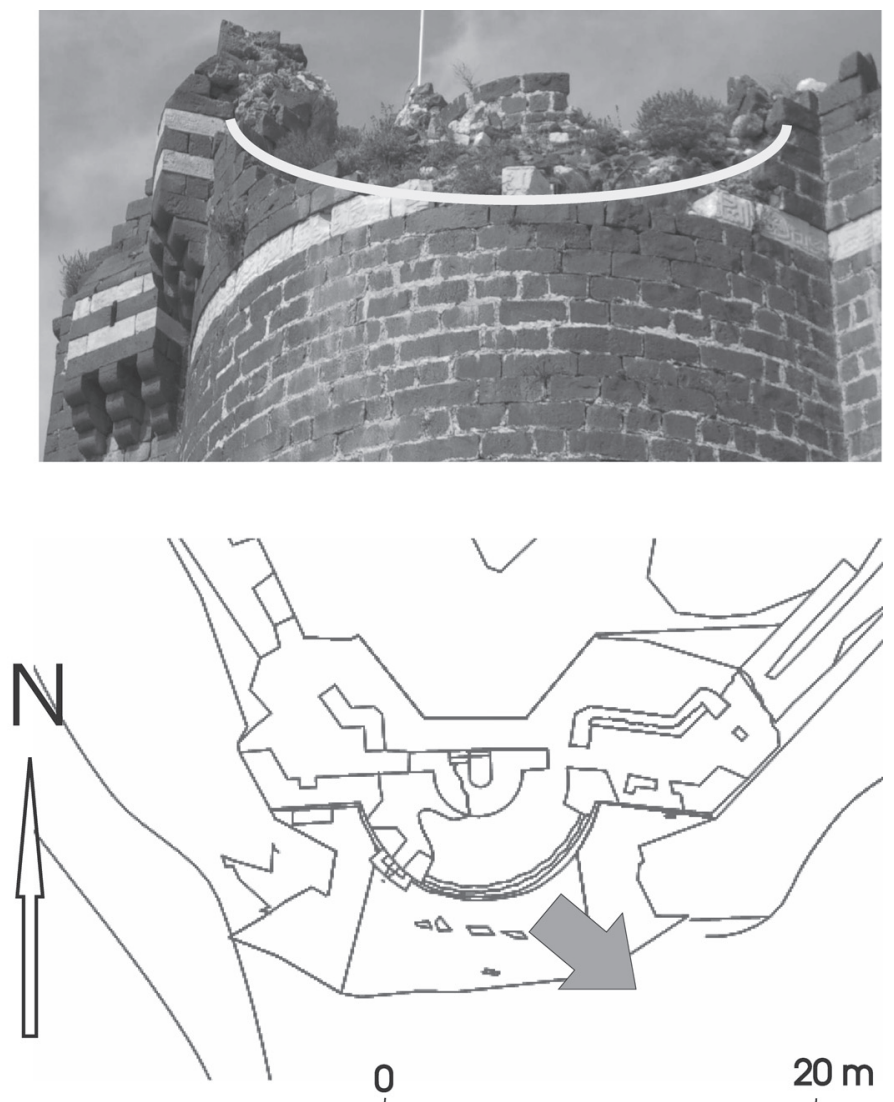

Figure 9. Symmetrical, scoop-like damage affecting top of Mamluk tower facing toward $130^{\circ} \mathrm{SE}$. Both upper, thin $(140 \mathrm{~cm})$ and lower, thick $(>3 \mathrm{~m})$ portions of wall collapsed toward SE (arrow). Two box machicolations are visible on top left. 


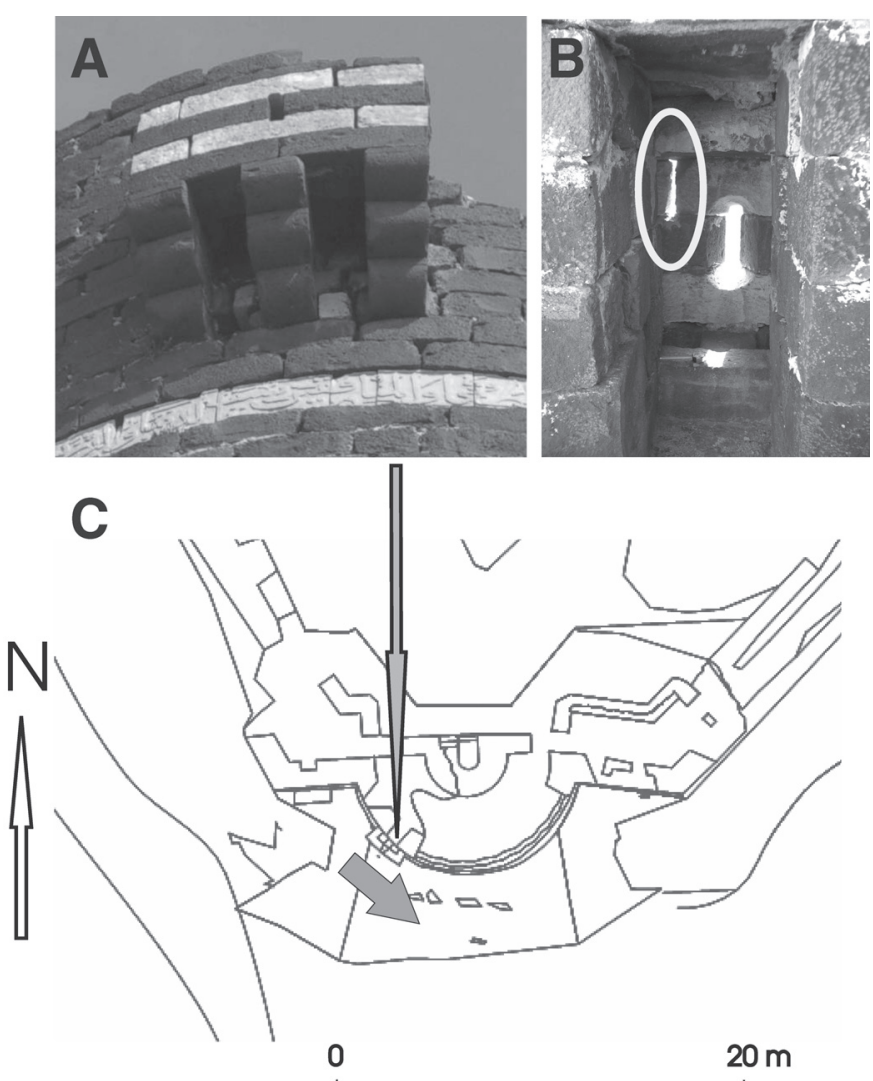

Figure 10. (A) Battlement with box machicolation suffered in-plane extension in $120^{\circ} \mathrm{SE}$ direction due to extension of the supporting wall. The upper 12 rows of ashlars have been displaced. Gaps between ashlars of the white stone are particularly wide, while blocks of the lowermost white row are still adjacent to each other. This is considered to be hard evidence for vibrations affecting the top of the Mamluk tower. Box is $\sim 2 \mathrm{~m}$ wide. (B) Same box machicolation viewed from inside. Besides the observation slot in the center, there is a $10-\mathrm{cm}$ wide gap between adjoining ashlars on the left (encircled), testifying to in-plane shaking. Extension is parallel with box machicolation face, in $120-300^{\circ} \mathrm{SE}-\mathrm{NW}$ azimuth. Walk is $70 \mathrm{~m}$ wide. (C) Location of the semicircular Mamluk tower within the southern part of the citadel. Thin arrow points to the box machicolation that underwent extension. Wide gray arrow indicates direction of extension.

The heaviest possible damages inflicted by pre-gunpowder warfare were created by trebuchets (highly evolved catapults), throwing stone balls up to several hundred kilograms in weight against walls and onto roofs. The southern side of the donjon wall, most exposed to incoming projectiles, bears only minor fractures of conchoidal shape, witnesses of minor hits.

The only really efficient siege tactic, mining, yielded collapse of walls. This method helped Sultan Qalawun's army to take Al-Marqab in 1285 by undermining the southern tower. No traces of the mine were found. This gravity-induced failure, subsidence, has different geometrical features than those yielded by lateral seismic shaking.

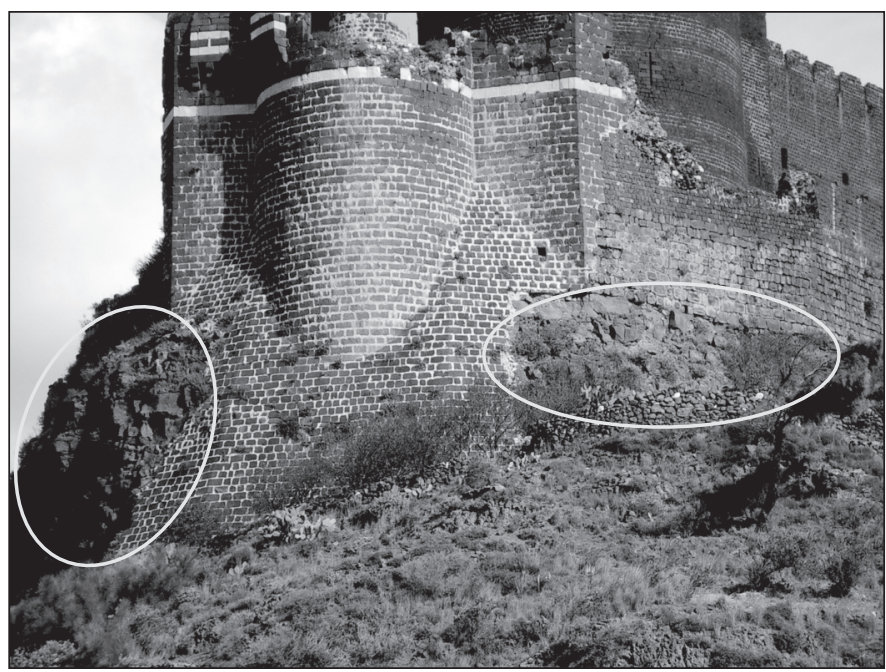

Figure 11. Crusader donjon (round tower partly hidden in background) and a later addition, Muslim southern tower built by Sultan Qalawun after his successful siege in 1285, bearing a row of white ashlars in the foreground. Both were firmly erected on several-meter-thick, unweathered vesicular basalt lava flow of Pliocene age (encircled), as seen on both sides of the glacis (inclined wall). Muslim tower is $20 \mathrm{~m}$ wide from corner to corner.

A common source of damage, original construction defects, can be excluded by examining the surviving portions of the southern sector of Al-Marqab citadel. Mortar is still rock-solid in the failed walls. Textbook examples of subsidence are missing. Therefore, a seismic origin of damages is highly probable.

\section{Dating Damages}

The first archaeological excavation in Al-Marqab started in 2007; therefore, a large proportion of the castle fabric is still undated. However, a relative chronology (architectural stratigraphy as understood by Galadini et al., 2006) can be readily established for the buildings studied in this project. Muslim-built portions of the circumferential wall, especially the southernmost tower in the outer enceinte, are decorated with a frieze-like white row of ashlars within the black basalt wall. These blocks bear an Arabic inscription, testifying to its construction by the sultan AlMansur Qalawun (Mamluk sultan from 1279 to 1290), who took the castle in 1285 (Fig. 12).

The donjon is certainly a Hospitaller construction and thus dates from after the order acquired the castle in 1187. Besides architectural design and the sheer size of the building, which could hardly have been financed by a private lord, the first results of the geophysical surveys also seem to support this dating. A georadar survey carried out inside the castle chapel (unequivocally accepted to have been the first Hospitaller construction on the site) detected the contours of a rectangular structure. Its position and the thickness of its wall, exceeding $3 \mathrm{~m}$, make it a likely 


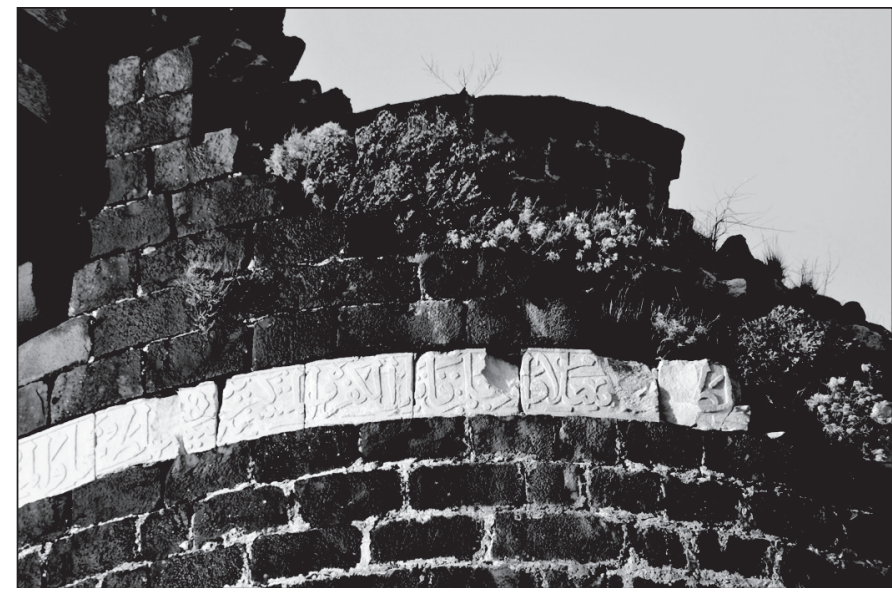

Figure 12. Portion of an Arabic inscription on the southern tower bearing the name of Sultan Qalawun, who conquered Al-Marqab in A.D. 1285. The full text says "This well-guarded fortress has been conquered and this tower rebuilt by Sultan Qalawun in months of the year [H.] 684. This work was executed under the direction of Balaban al-Mansuri," as read and published by Max van Berchem in his Voyage en Syrie, on p. 303 in the early twentieth century (fide Deschamps, 1973, p. 273).

candidate for being the residential tower of the Mazoir family. This assumption is further strengthened by the presence of an old cistern incorporated in the southern walls of the chapel that stands in the center of the conjectured Mazoir tower. The presence of rock-cut cisterns under the main towers of eminent Crusader castles in the twelfth century is very common. Because the defense of the southern part of the castle mountain requires the presence of a dominant building, the substitution of the Mazoir square tower by the chapel must have been closely followed by the building of the new donjon, which is likely to have taken place in the $1190 \mathrm{~s}$.

The supposed construction date of the donjon soon after 1187 and the precise dating of the southern corner tower after the successful Muslim siege of 1285 put constraints on dating the earthquake damages (Fig. 13).

\section{DISCUSSION}

\section{Mechanism of Damages}

Indirect earthquake damage to buildings is caused by ground shaking. If the frequency of earth vibrations is close to the frequency of resonance of the building, excitation will occur, damage will be pervasive, and the building will collapse. If frequencies widely differ, the building will survive, possibly intact (for the spectacular example of the Pont du Gard in France, see Volant et al., 2009). Likely, this is the primary cause why halls with lower proportions, e.g., the Main Hall, collapsed (Major et al., 2010), while tall, stout buildings like the donjon survived each earthquake for $800 \mathrm{yr}$.
The donjon of Al-Marqab, being of $20 \mathrm{~m}$ diameter, $24 \mathrm{~m}$ height, and having walls up to $5 \mathrm{~m}$ thick, is a robust structure. Height/thickness ratio is $h / t=5$, indicating extremely strong and earthquake-resistant construction (Lourenço et al., 2007). We note that Eurocode 8 building codes allow a maximum of $h / t=9$ for earthquake-resistant buildings (Anonymous, 2003) In-plan area ratio (Lourenço and Roque, 2006) is 57\%, again an overly resistant structure against all kinds of earthquake resonance. Eurocode 8 recommends 5\%-6\% for regular structures. A minimum value of $10 \%$ is recommended for historical masonry buildings (Meli, 1998). For simplicity sake, high seismicity cases can be assumed to be those where design ground acceleration for rock-like soils exceeds $0.2 g$.

Area to weight ratio (Lourenço and Roque, 2006) is $10.4 \mathrm{~m}^{2} /$ MN, i.e., more than $8 \times$ higher than recommended (Meli, 1998).

Seismological modeling of a smaller tower in Roman Tolbiacum, Germany ( $8.3 \mathrm{~m}$ diameter, $8 \mathrm{~m}$ high, having an up to $3.1-\mathrm{m}$-thick wall), yielded $0.12 \mathrm{~m}$ horizontal and $0.06 \mathrm{~m}$ vertical displacement at the top of the tower in case of a $M>6.4$ earthquake (EMS98 intensity IX) (Hinzen, 2005). Deformation of the Al-Marqab donjon (Fig. 5) was of similar dimensions.

A $0.06 \mathrm{~m}$ vertical displacement is more than enough to reduce friction between ashlars of the Mamluk tower while extension of the box machicolation and adjoining walls is in progress during shaking.

\section{How Many Successive Earthquakes?}

The Syrian earthquake catalogue (Sbeinati et al., 2005) lists a large number of damaging earthquakes in the coastal region. The name of Al-Marqab (or Margat) is mentioned for tens of them. Probably most of them caused appreciable damage to part of the castle. Because the donjon and the towers belong to the most heavily constructed portions of the citadel, we assume that only earthquakes with the highest intensity caused any damage to them.

Earthquake 1 produced the V-shaped extrusion on top of the donjon $\left(60^{\circ}-240^{\circ}\right)$. This earthquake occurred after the donjon was completed and before the southern tower was built: there are no traces at all of this damage direction on the southern tower. Earthquake 1 occurred during the interval between 1187 and 1285, after Hospitallers took the castle and before Mamluk occupation. A candidate earthquake is that of 1202, this being the largest in the Middle East ever recorded (see Table 1).

Earthquake 2 produced the U-shaped damage to the southern corner tower. Additionally an extension of the top of the tower and of the box machicolation occurred in $120-300^{\circ}$ direction. We can give only a terminus post quem date: it happened after 1285, i.e., during the Muslim period of Al-Marqab. In addition, a relative intensity of this quake would be lesser than that of the 20 May 1202, since it did not cause any visible damage to the donjon.

While caution must be exercised in assigning damage azimuth to epicenter direction, according to Ambraseys and Melville 


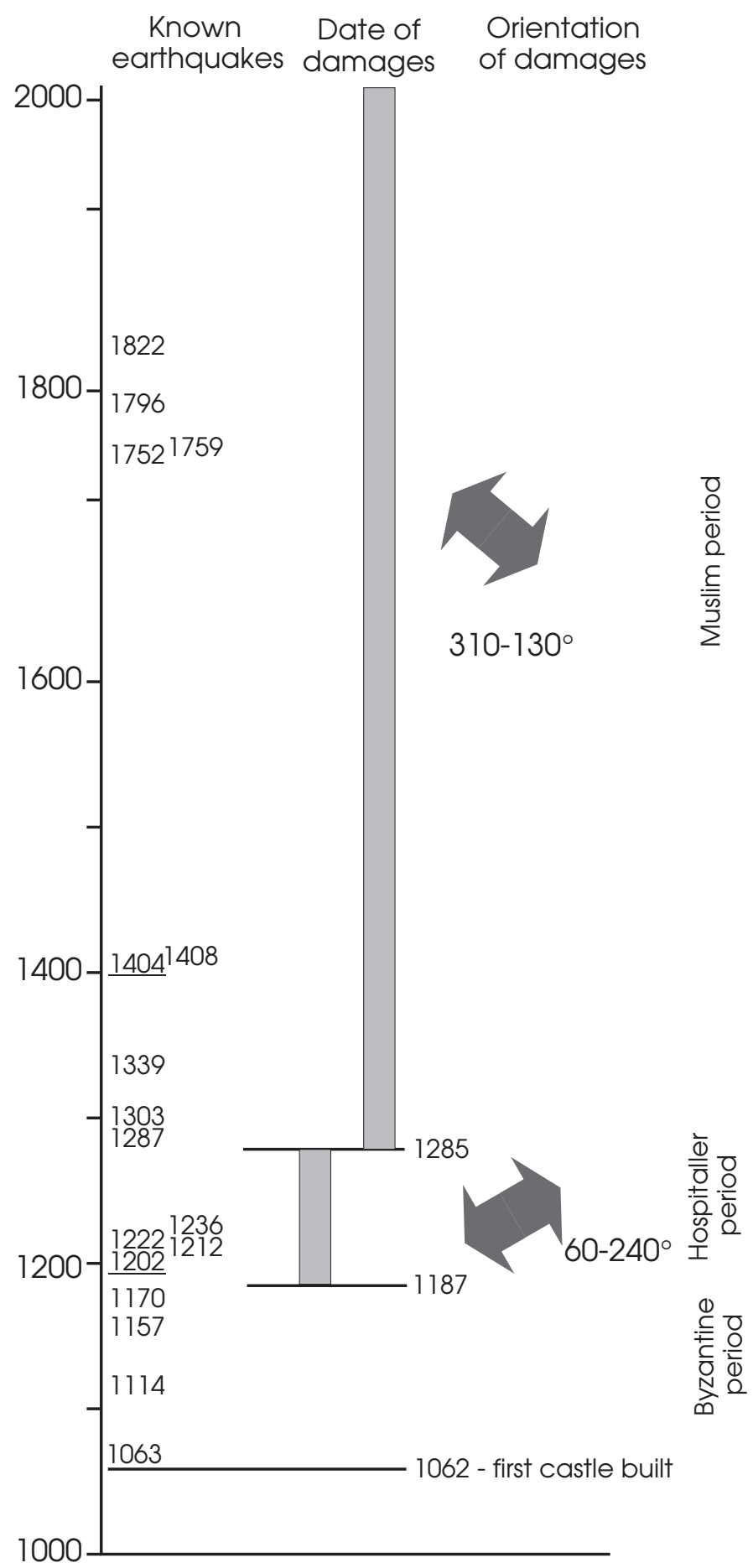

Figure 13. Dating of major earthquake damages in the history of AlMarqab citadel. Known earthquakes are listed after Sbeinati et al. (2005); most damaging seismic events are underlined. Double arrows refer to vibration directions as calculated from orientation of failures. These display an earlier, $60^{\circ}-240^{\circ}$ direction as shown by V-shaped extrusion of the donjon and symmetrical extensional failure of room M3 (Figs. 7-8). This is probably due to the 20 May 1202 earthquake. The later, $310^{\circ}-130^{\circ}$-directed vibration is seen on the southern tower, built during the Muslim period (Fig. 9). It occurred any time after 1285 and may be correlated to the 1404 (and/or 1408?) earthquake.
(1988), the epicenter of the 1202 earthquake was south of AlMarqab, in the Bekaa Valley, while all major successive earthquakes had their epicenters to the north, near Aleppo (see also Fig. 1).

\section{Implications for the 1202 Earthquake}

The 1202 earthquake, widely discussed in various seismological papers (e.g., Ambraseys and Melville, 1988; Ellenblum et al., 1998; Kovach and Nur, 2006), has been considered as the most damaging earthquake in the Middle East. However, there are various, as yet unreported problems concerning dating, intensity, epicenter, and magnitude. Each of them will be discussed here briefly.

Date

Two contemporary Latin sources-written within days of the earthquake-report a damaging earthquake to large part of the then-Christian territories of the Middle East, including AlMarqab, as occurring in the early hours of 20 May 1202, a Monday. In a letter dated June of the same year, Geoffrey of Donjon, master of the Knights Hospitallers, reported to King Sancho VII of Navarra that "Al-Marqab had been badly affected but could be able to hold their own against hostile incursions unless there were more tremors" (Mayer, 1972, p. 303).

The letter of Philip du Plessis, master of the Knights Templars, written at about the same time as Geoffrey's letter, describes historical and environmental events between 1 November 1201 and 2 June 1202. His date for the earthquake is also 20 May 1202. Understandably, he does not mention the Hospitaller castle of AlMarqab, but describes damages elsewhere (Mayer, 1972).

Many more Arabic historians report about an earthquake in Sha'ban month of H. 597 causing extensive damages from Egypt to Syria and northward. All of them cite or copy the contemporary authors Ibn Al-Athir (1999, v. X, p. 181) and Ibn Al-Jawzi (1952, p. 477-478), who write that a major earthquake damaged the Middle East between Egypt, Syria, and toward the north in the month Sha'ban H. 597. This date equals 7 May to 4 June 1201 A.D. None of them mentions any earthquake for H. 598, i.e., A.D. 1202. Since Shaban H. 597 overlaps the 20 May date of the contemporary Latin sources, although offset by a year, we can safely assume that there was only one major earthquake in the years 1201 and 1202. An original one-year error of Arabic historians - possibly working years or decades later than the eventhas been inherited in successive works. The seismic catalogue of Sbeinati et al. (2005, p. 389-391) mentions both 1201 and 1202 earthquakes, listing all of them under the 20 May 1202 event. Ambraseys and Melville (1988) provide an extensive discussion of the event.

By this reasoning, we can confidently exclude the possibility of amalgamation (Ambraseys, 2005b) of two successive earthquakes by historical sources. For further detailed discussion of dating problems in Arabic sources, see Ambraseys and Melville (1988). 


\section{Intensity}

Ambraseys and Melville (1988) suggested intensity VII on the MSK scale for Al-Marqab based on historical documents only (the reports of Geoffrey of Donjon and on the history of Al-Jawzi). They considered it to be a shallow, large-magnitude multiple event, with widely felt aftershocks and a tsunami. While modified Mercalli intensity VII is the damage threshold for many archaeological sites (Kovach and Nur, 2006), we assume that damages at Al-Marqab citadel related to the 1202 earthquake require a larger intensity. The donjon, having up to 5-m-thick walls, is certainly a more earthquake-resistant structure than any ordinary city house, even palace. Since the donjon bears magnificent traces of only one major earthquake, occurring between 1187 and 1285, we suggest that the 1202 earthquake was of intensity VIIIIX at Al-Marqab (based on Rapp, 1986, his Table I). An intensity VIII value is corroborated by Geoffrey of Donjon's letter, where he states that although Al-Marqab was heavily damaged, it can resist enemy attacks. The donjon - intact for military purposesis located at the southernmost tip of the citadel, fully protecting it from any siege attacking from the mountain to the south.

Increase of shaking intensity is justified by the statement of Geoffrey of Donjon, that Al-Marqab was heavily damaged (in those buildings that we cannot see now, probably many of them in the suburbium); however, this statement is uncertain. The donjon is an extremely earthquake-resistant construction (see previous). The fact that it has suffered any major damage, like the V-shaped wedge extrusion, is a signature that certainly more than "some masonry walls" (Rapp, 1986) fell. Estimating intensity as $\mathrm{M}_{\mathrm{M}}=\mathrm{IX}$ might be too heavy a statement—we did not observe any buildings yet shifted off their foundations.

\section{Epicenter}

An epicenter or a long fault source has been outlined by mapping historical records of damages and their intensity (Ambraseys and Melville, 1988; Kovach and Nur, 2006). The zone of strongest shaking extends along the Dead Sea fault zone from Nablus in the south to Arqa in the north, enclosing $M_{M}=$ VIII+ and $\mathrm{M}_{\mathrm{M}}=$ IX intensities (Ambraseys and Melville, 1988). Their map suggests that the regular left-lateral faulting of the Dead Sea transform caused the earthquake. The Upper Jordan sector certainly moved at least $1.6 \mathrm{~m}$ sinistrally (Ellenblum et al., 1998). An epicenter was calculated at $34.1^{\circ} \mathrm{N}, 36.1^{\circ} \mathrm{E}$ (Ambraseys, 2009). Landslides and/or rockfalls in Mount Lebanon near Baalbek (Ibn Al-Jawzi, 1952), and ${ }^{14} \mathrm{C}$ data from trenching across visible portions indicate that the Yammouneh fault was active in 1202, but not at any point since (Daëron et al., 2005).

However, the tsunami damaging the eastern part of Cyprus, as reported by the Arab historian Ibn Al-Jawzi (1952), suggests an offshore earthquake instead, either as a sole event or as an event associated with the activity of inland faults. The Yammouneh and other bounding faults are less than $50 \mathrm{~km}$ from the offshore thrust faults yielding the transpressional uplift of Mount Lebanon (Elias et al., 2003). We allow several alternatives. Alternative 1 includes a major displacement along the Dead Sea fault that was associated with activity of offshore faults, causing a tsunami that reached Cyprus in 1202. A similar event of higher magnitude has been identified for causing the A.D. 551 Beirut-Tripoli earthquake and tsunami offshore Lebanon (Elias et al., 2007). We prefer this scenario.

We cannot exclude an alternative 2, which needs to include the direction of donjon damage besides the intensity assessment. Azimuth $240^{\circ}$ allows us to introduce a hypothesis of a shallow thrust below the Jabal Ansariyya, breaking the surface offshore. This feature allows a local source for the earthquake, with lesser magnitude to reach $\mathrm{M}_{\mathrm{M}}=\mathrm{VIII}+$ and even $\mathrm{M}_{\mathrm{M}}=\mathrm{IX}$ intensities.

There is a possibility of an alternative 3 , consisting of an earthquake-related submarine landslide causing the tsunami.

\section{Magnitude}

Ambraseys and Melville (1988) assigned a magnitude of 7.5 to the 1202 earthquake. The area suffering shaking equal or greater than modified Mercalli intensity VII (the damage threshold for many archaeological sites) in 1202 is roughly $60,000 \mathrm{~km}^{2}$ as outlined by Kovach and Nur (2006). Their cross-plot of earthquake magnitude versus area of intensity VII allows an estimate of magnitude 7.8 for this earthquake. They encircle $\sim 60,000 \mathrm{~km}^{2}$ on their Figure 3, while assuming only $20,000 \mathrm{~km}^{2}$ when reading for a magnitude 7.6 only on their Figure 2. This seems unrealistic, because M 7.8 would need $400 \mathrm{~km}$ of coseismic fault rupture (Meghraoui, 2010, personal commun.). However, if we accept that Al-Marqab suffered at an intensity at least VII+, and possibly VIII, then the area of VII shaking will be significantly larger than outlined by Kovach and Nur (2006). An $~ 50$ km northward extension of the VII shaking increases the shaken area northward by at least $50 \mathrm{~km}$, increasing shaken territory to $70,000 \mathrm{~km}^{2}$, and increasing calculated magnitude to 7.9. One has to bear in mind, however, that correlation of magnitude and shaken area is very weak!

\section{CONCLUSIONS}

We distinguished traces of two major, successive earthquakes based on failures observed in Al-Marqab castle. Dating was conducted by historical documents and archaeological dating. Earthquake 1 consisted of vibration in SW-NE plane, damaging the donjon and room M3. It was a major event between 1187 and 1285 , possibly the 1202 earthquake. Earthquake 2 consisted of vibration in NE-SW plane. It damaged the southern tower $+\mathrm{NW}$ corner of the donjon. It was also a major but lesser event than number 1 , and it occurred after 1285. Candidates are the 1404 and 1759 events reported in Sbeinati et al. (2005).

\section{ACKNOWLEDGMENTS}

Our thanks are due to Tamás Borosházy, architect, SyroHungarian Archaeological Mission (SHAM) member, for providing architectural plans of Al-Marqab castle. The authors are grateful for the extremely helpful remarks of Mustapha 
Meghraoui (Strasbourg, France) and of an anonymous reviewer; both improved the manuscript significantly. This study was supported by Hungarian National Science Foundation grants K67.583 and PD77.585. This is Syro-Hungarian Archaeological Mission publication no. 5. This article is a contribution to the UNESCO-funded International Geoscience Programme IGCP 567, "Earthquake Archaeology: Archaeoseismology along the Alpine-Himalayan Seismic Zone."

\section{REFERENCES CITED}

Akyüz, S., and Altunel, E., 2001, Geological and archaeological evidence for post-Roman earthquake surface faulting at Cibyra, SW Turkey: Geodinamica Acta, v. 14, p. 95-101, doi: 10.1016/S0985-3111(00)01057-3.

Al-Tarazi, E.A., and Korjenkov, A., 2007, Archaeoseismological investigation of the ancient Ayla site in the city of Aqaba, Jordan: Natural Hazards, v. 42, p. 47-66, doi: 10.1007/s11069-006-9045-6.

Altunel, E., Stewart, I.S., Barka, A., and Piccardi, L., 2003, Earthquake faulting at ancient Cnidus, SW Turkey: Turkish Journal of Earth Sciences, v. 12, p. $137-151$.

Ambraseys, N.N., 2005a, Archaeoseismology and neo-catastrophism: Seismological Research Letters, v. 76, no. 5, p. 560-564, doi: 10.1785/gssrl 76.5.560.

Ambraseys, N.N., 2005b, The seismic activity in Syria and Palestine during the middle of the 8th century: An amalgamation of historical earthquakes: Journal of Seismology, v. 9, p. 115-125, doi: 10.1007/s10950-005 -7743-2.

Ambraseys, N.N., 2006, Earthquakes and archaeology: Journal of Archaeological Science, v. 33, p. 1008-1016, doi: 10.1016/j.jas.2005.11.006.

Ambraseys, N.N., 2009, Earthquakes in the Mediterranean and Middle East: A Multidisciplinary Study of Seismicity up to 1900: Cambridge, UK, Cambridge University Press, $968 \mathrm{p}$.

Ambraseys, N.N., and Barazangi, M., 1989, The 1759 earthquake in the Bekaa Valley: Implications for earthquake hazard assessment in the East Mediterranean region: Journal of Geophysical Research, v. 94, p. 4007-4013, doi: 10.1029/JB094iB04p04007.

Ambraseys, N.N., and Melville, C.P., 1988, An analysis of the Eastern Mediterranean earthquake of 20 May 1202, in Lee, W.H.K., Meyers, H., and Shimazaki, K., eds., Historical Seismograms and Earthquakes of the World: San Diego, Academic Press, p. 181-200.

Anonymous, 2003, Comité Européen de Normalisation, Eurocode 8: Design of Structures for Earthquake Resistance, prEN 1998-1: Brussels, Comité Européen de Normalisation, $94 \mathrm{p}$.

Anzani, A., Binda, L., and Melchiorri, G., 1995, Time dependent damage of rubble masonry walls, in West, H., ed., 4th International Masonry Conference Proceedings: London, British Masonry Society, p. 341-351.

Anzani, A., Garavaglia, E., and Binda, L., 2009, Long-term damage of historic masonry: A probabilistic model: Construction \& Building Materials, v. 23 , no. 2, p. 713-724, doi: 10.1016/j.conbuildmat.2008.02.010.

Bottari, C., 2005, Ancient constructions as markers of tectonic deformation and strong seismic motions: Pure and Applied Geophysics, v. 162, p. 761-765, doi: 10.1007/s00024-004-2639-6.

Burgtorf, J., 2007, Die Herrschaft der Johanniter in Margat im Heiligen Land, in Czaja, R., and Sarnowsky, J., eds., Die Ritterorden als Träger der Herrschaft: Territorien, Grundbesitz und Kirche. Ordines militares: Colloquia Torunensia Historica, v. XIV, p. 27-57.

Caputo, R., and Helly, B., 2005, Archaeological evidences of past earthquakes: A contribution to the Sha of Thessaly, central Greece: Journal of Earthquake Engineering, v. 9, no. 2, p. 199-222, doi: 10.1142/S136324690500192X.

Daëron, M., Klinger, Y., Tapponnier, P., Elias, A., Jacques, E., and Sursock, A., 2005, Sources of the large A.D. 1202 and 1759 Near East earthquakes: Geology, v. 33, no. 7, p. 529-532, doi: 10.1130/G21352.1.

Deschamps, P., 1973, Les Châteaux des Croisés en Terre Sainte III. La Défense du Comté de Tripoli et de la Principauté d'Antioche: Paris, Paul Geuthner, $273 \mathrm{p}$.

Elias, A., Tapponnier, P., Jacques, E., Daëron, M., Klinger, Y., and Sursock, A., 2003, Quaternary deformation associated with the Tripoli-Roum thrust, and the rise of the Lebanese coast: Geophysical Research Abstracts, v. 5, p. 10137.

Elias, A., Tapponnier, P., Singh, S.S., King, G.C.P., Daëron, M., Carton, H., Sursock, A., Jacques, E., Jomaa, R., and Klinger, Y., 2007, Active thrusting offshore Mount Lebanon: Source of the tsunamigenic A.D. 551 Beirut-Tripoli earthquake: Geology, v. 35 , no. 8, p. 755-758, doi: 10.1130/G23631A.1.

Ellenblum, R., Marco, S., Agnon, A., Rockwell, T., and Boas, A., 1998, Crusader castle torn apart by earthquake at dawn, 20 May 1202: Geology, v. 26, no. 4, p. 303-306, doi: 10.1130/0091-7613(1998)026<0303 :CCTABE $>2.3 . \mathrm{CO} ; 2$

Ferretti, D., and Bažant, Z.P., 2006, Stability of ancient masonry towers: Stress redistribution due to drying, carbonation and creep: Cement and Concrete Research, v. 36, p. 1389-1398, doi: 10.1016/j.cemconres.2006.03.014.

Galadini, F., Hinzen, K.-G., and Stiros, S., 2006, Archaeoseismology: Methodological issues and procedure: Journal of Seismology, v. 10, p. 395-414, doi: $10.1007 / \mathrm{s} 10950-006-9027-x$.

Galli, P., and Galadini, F., 2001, Surface faulting of archaeological relics. A review of case histories from the Dead Sea to the Alps: Tectonophysics, v. 335, p. 291-312, doi: 10.1016/S0040-1951(01)00109-3.

Galli, P.A.C., Naso, J.A., Capini, S., Giocoli, A., Hailemikael, S., Piscitelli, S., Rizzo, E., and Scaroina, L., 2008, Faulting of the Roman aqueduct of Venafrum (Italy); investigation methodology and preliminary results, in 31st European Seismological Commission (ESC) General Assembly, 2008, Hersonissos, Crete, Greece, Proceedings and Abstracts, p. 94-100.

Guidoboni, E., and Comastri, A., 1997, The large earthquake of 8 August 1303 in Crete: Seismic scenario and tsunami in the Mediterranean area: Journal of Seismology, v. 1, p. 55-72, doi: 10.1023/A:1009737632542.

Guidoboni, E., Bernardini, F., and Comastri, A., 2004, The 1138-1139 and 1156-1159 destructive seismic crises in Syria, south-eastern Turkey and northern Lebanon: Journal of Seismology, v. 8, p. 105-127, doi: 10 1023/B:JOSE.0000009502.58351.06

Hancock, P.L., and Altunel, E., 1997, Faulted archaeological relics at Hierapolis (Pamukkale, Turkey): Journal of Geodynamics, v. 24, p. 21-36, doi: 10.1016/S0264-3707(97)00003-3.

Hinzen, K.-G., 2005, The use of engineering seismological models to interpret archaeoseismological findings in Tolbiacum, Germany: A case study: Bulletin of the Seismological Society of America, v. 95, no. 2, p. 521-539, doi: $10.1785 / 0120040068$.

Hinzen, K.-G., 2008, Can ruins indicate a back azimuth?: Seismological Research Letters, v. 79, no. 2, p. 290.

Hinzen, K.-G., 2009, Simulation of toppling columns in archaeoseismology: Bulletin of the Seismological Society of America, v. 99, no. 5, p. 28552875, doi: 10.1785/0120080241.

Ibn Abdazzahir, 1946, Ibn Abdazzahir, Esprit du guerre sainte (translated by Jean Sauvaget), in Historiens Arabes: Pages Choisies, Traduites et Présentées: Paris, Librairie d'Amérique et d'Orient, p. 126-129.

Ibn Al-Athir, 1999, 'Izz ad-Din Abu'l-Hasan 'Ali ibn Abu'l-Karam Muhammad ibn Muhammad Abu 'Abd al-Karim ibn 'Abd al-Wahid al-Shaybani, Al-kamil fi'l-tarikh [The Complete History], 11 vols., ed. 'Umar 'Abd alSalam Tadmuri, Dar al-Kitab al-'Arabiyy: Beirut, Lebanon, Dar al-Kitab al-'Arabi Publisher, 3500 p. (in Arabic).

Ibn Al-Jawzi, 1952, Shams al-Din Abu'l-Muzaffar Yusuf ibn Qazawghali, Mirat al-zaman fi ta'rikh al-al-a'yan (H. 590-654): [The Mirror of Times in the History of the Notables]: Haydarabad-al-Dakan, India, Dā'irat'l-Ma'arif al-'Uthmaniyya Publisher, $250 \mathrm{p}$.

Kamh, G.M.E., Kallash, A., and Azzam, R., 2008, Factors controlling building susceptibility to earthquakes: 14-year recordings of Islamic archaeological sites in Old Cairo, Egypt: A case study: Environmental Geology, v. 56, p. 269-279, doi: 10.1007/s00254-007-1162-3.

Karakhanian, A.S., Trifonov, V.G., Ivanova, T.P., Avagyan, A., Rukieh, M., Minini, H., Dodonov, A.E., and Bachmanov, D.M., 2008a, Seismic deformation in the St. Simeon monasteries (Qal'at Sim'an), northwestern Syria: Tectonophysics, v. 453, p. 122-147, doi: 10.1016/j.tecto.2007.03.008.

Karakhanian, A.S., Trifonov, V.G., Ivanova, T.P., Dodonov, A.E., Bachmanov, D.M., Minini, H., and Al-Kafri, A.M., 2008b, Seismic influence on archaeological objects in Syria, in 31st General Assembly of the European Seismological Commission (ESC) 2008, Hersonissos, Crete, Greece, 7-12 September 2008, p. 182-189.

Karcz, I., and Kafri, U., 1978, Evaluation of supposed archaeoseismic damage in Israel: Journal of Archaeological Science, v. 5, p. 237-253, doi: 10.1016/0305-4403(78)90042-0. 
Kázmér, M., 2008, Earthquake damages in Al-Marqab citadel, Syria, in Török, Á., and Vásárhelyi, B., eds., Mérnökgeológia-Kőzetmechanika: Budapest, Múegyetemi Kiadó (Technical University Press), p. 159-168.

Kennedy, H., 1994, Crusader Castles: Cambridge, UK, Cambridge University Press, $x v+221 \mathrm{p}$.

Kilian, K., 1980, Zum Ende der mykenischen Epoche in der Argolis: Jahrbuch der Römisch-Germanischen Zentralmuseums Mainz, v. 27, p. 166-195.

Korjenkov, A.M., and Mazor, E., 1999, Seismogenic origin of the ancient Avdat Ruins, Negev Desert, Israel: Natural Hazards, v. 18, p. 193-226, doi: 10 .1023/A:1026488932377.

Korjenkov, A.M., and Mazor, E., 2003, Archaeoseismology in Mamshit (southern Israel): Cracking a millennia-old code of earthquakes preserved in ancient ruins: Archaologischer Anzeiger, v. 2003, no. 2, p. 51-82.

Kovach, R.L., and Nur, A., 2006, Earthquakes and archeology: Neocatastrophism or science?: Eos (Transactions, American Geophysical Union), v. 87 , no. 32, p. 317, doi: 10.1029/2006EO320003.

Lamprecht, H.-O., 2001, Opus caementitium-Bautechnik der Römer [Cemented work-Construction technique of the Romans]: Köln, Römisch-Germanisches Museum \& Düsseldorf, Bau+Technik Verlag, 264 p. (in German).

Lourenço, P.B., and Roque, J.A., 2006, Simplified indexes for the seismic vulnerability of ancient masonry buildings: Construction \& Building Materials, v. 20, p. 200-208, doi: 10.1016/j.conbuildmat.2005.08.027.

Lourenço, P.B., Krakowiak, K.J., Ferriandes, F.M., and Ramos, L.F., 2007, Failure analysis of Monastery of Jerónimos, Lisbon: How to learn from sophisticated numerical models: Engineering Failure Analysis, v. 14, p. 280-300, doi: 10.1016/j.engfailanal.2006.02.002.

Major, B., Buzás, G., and Al-Ajji, E., 2010, Excavations of the Syro-Hungarian Archaeological Mission at Al-Marqab, in Edbury, P., ed., The Military Orders, Volume 5: Oxford, UK, Ashgate (in press).

Marco, S., 2008, Recognition of earthquake-related damage in archaeological sites: Examples from the Dead Sea fault zone: Tectonophysics, v. 453, p. 148-156, doi: 10.1016/j.tecto.2007.04.011.

Martini, K., 1996, Masonry Damage Modes at Pompeii: http://urban.arch.virginia .edu/pompeii/masonry/masonry-1.html (accessed 6 October 2008)

Mayer, H.E., 1972, Two unpublished letters on the Syrian earthquake of 1202, in Hanna, S.A., ed., Medieval and Middle Eastern Studies in Honour of Aziz Suryal Atiya: Leiden, E.J. Brill, p. 295-310. (Reprinted in Kreuzzüge und lateinischer Osten, Variorum Reprints, Leiden, 1983.)

Meghraoui, M., Gomez, F., Sbeinati, R., Van der Woerd, J., Mouty, M., Darkal, A.N., Darawcheh, R., Hijazi, F., Al-Ghazzi, R., and Barazangi, M., 2003, Evidence for 830 years of seismic quiescence from palaeoseismology, archaeoseismology, and historical seismicity along the Dead Sea fault in Syria: Earth and Planetary Science Letters, v. 210, p. 35-52, doi: 10.1016/ S0012-821X(03)00144-4.

Meli, R., 1998, Structural Engineering of Historical Buildings: Mexico-City, Fundación ICA, 312 p. (in Spanish)

Mistler, M., Butenweg, C., and Meskouris, K., 2006, Modelling methods of historic masonry buildings under seismic excitation: Journal of Seismology, v. 10, p. 497-510, doi: 10.1007/s10950-006-9033-z.

Nikonov, A., 1988, On the methodology of archaeoseismic research into historical monuments, in Marinos, I., and Koukis, G., eds., The Engineering Geology of Ancient Works, Monuments and Historical Sites, Preservation and Protection: Rotterdam, Balkema, p. 1315-1320.

Nur, A., and Burgess, D., 2008, Apocalypse: Earthquakes, Archaeology and the Wrath of God: Princeton, New Jersey, Princeton University Press, 319 p.

Penazzi, D., Valluzzi, M.R., Saisi, A., Binda, L., and Modena, C., 2001, Repair and strengthening of historic masonry buildings in seismic areas, in International Millennium Congress "More than Two Thousand Years in the History of Architecture Safeguarding the Structure of Our Architectural Heritage": Bethlehem (Palestine), v. 2, Section V, 7 p.; http:// home.anadolu.edu.tr/ yguney/Cemil_historical/Historical_Buildings/ oct_2006/strengthening/binda197.pdf (accessed 1 August 2010).

Rapp, G., Jr., 1986, Assessing archaeological evidence for seismic catastrophes: Geoarchaeology, v. 1, p. 365-379, doi: 10.1002/gea.3340010403.
Reicherter, K.R., Jabaloy, A., Galindo-Zaldívar, J., Ruano, P., Becker-Heidmann, P., Morales, J., Reiss, S., and González-Lodeiro, F., 2003, Repeated paleoseismic activity of the Ventas de Zafarraya fault (S Spain) and its relation with the 1883 Andalusian earthquake: International Journal of Earth Sciences, v. 92, p. 912-922, doi: 10.1007/s00531-003-0366-3.

Sbeinati, M.R., Darawcheh, R., and Mouty, M., 2005, The historical earthquakes of Syria: An analysis of large and moderate earthquakes from 1365 B.C. to 1900 A.D.: Annals of Geophysics, v. 48, no. 3, p. 347-435.

Sieberg, A., 1932, Untersuchungen über Erdbeben und Bruchschollenbau im östlichen Mittelmeergebiet [Research on earthquakes and tectonics in the Eastern Mediterranean]: Denkschriften der Medizinisch-Naturwissenschaftlichen Gesellschaft, Jena, v. 18, no. 2, p. 161-273 (in German)

Similox-Tohon, D., Sintubin, M., Muchez, Ph., Verhaert, G., Vanneste, K., Fernandez, M., Vandycke, S., Vanhaverbeke, H., and Waelkens, M., 2006, The identification of an active fault by a multidisciplinary study at the archaeological site of Sagalassos (SW Turkey): Tectonophysics, v. 420, p. 371-387, doi: 10.1016/j.tecto.2006.03.026.

Similox-Tohon, D., Sintubin, M., Muchez, Ph., Verhaert, G., Vanneste, K., Fernandez, M., Vandycke, S., Vanhaverbeke, H., and Waelkens, M., 2007, Erratum to "The identification of an active fault by a multidisciplinary study at the archaeological site of Sagalassos (SW Turkey)": Tectonophysics, v. 435, p. 55-62, doi: 10.1016/j.tecto.2007.02.011.

Sintubin, M., and Stewart, I.S., 2008, A logical methodology for archaeoseismology: A proof of concept at the archaeological site of Sagalassos, southwest Turkey: Bulletin of the Seismological Society of America, v. 98 , no. 5, p. 2209-2230, doi: 10.1785/0120070178.

Sintubin, M., Muchez, P., Similox-Tohon, D., Verhaert, G., Paulissen, E., and Waelkens, M., 2003, Seismic catastrophes at the ancient city of Sagalassos (SW Turkey) and their implications for seismotectonics in the BurdurIsparta area: Geological Journal, v. 38, p. 359-374, doi: 10.1002/gj.960.

Sintubin, M., Stewart, I.S., Niemi, T., and Altunel, E., 2008, Earthquake archaeology—Just a good story?: Seismological Research Letters, v. 79, no. 6, p. 767-768, doi: $10.1785 / \mathrm{gssrl} .79 .6 .767$.

Stiros, S.C., 1996, Identification of earthquakes from archaeological data: Methodology, criteria, and limitations, in Stiros, S.C., and Jones, R.E., eds., Archaeoseismology: British School at Athens, Fitch Laboratory Occasional Paper 7, p. 129-152.

Stiros, S.C., Laborel, J., Laborel-Deguen, F., Papageorgiou, S., Evin, J., and Pirazzoli, P.A., 2000, Seismic coastal uplift in a region of subsidence: Holocene raised shorelines of Samos Island, Aegean Sea, Greece: Marine Geology, v. 170, p. 41-58, doi: 10.1016/S0025-3227(00)00064-5.

Tomaževič, M., and Lutman, M., 2007, Heritage masonry buildings in urban settlements and the requirements of Eurocodes: The experience of Slovenia: International Journal of Architectural Heritage, v. 1, p. 108-130, doi: $10.1080 / 15583050601126186$.

Van Berchem, M., and Fatio, E., 1913-1915, Voyage en Syrie: Cairo, Imprimerie de l'Institut français d'archéologie orientale en Le Caire, 303 p.

Vasconcelos, G., Lourenço, P.B., Mouzakis, H., and Karapitta, L., 2006, Experimental investigations on dry stone masonry walls, in Hamid, A.A., chairman, Proceedings of the First International Conference on Restoration of Heritage Masonry Structures, Cairo, Egypt, 24-27 April 2006, p. P31-1P31-10.

Volant, Ph., Levret, A., Carbon, D., Scotti, O., Combescure, D., Verdel, T., Piant, A., and Laurent, Ph., 2009, An archaeo-seismological study of the Nîmes Roman aqueduct, France: Indirect evidence for an $M>6$ seismic event?: Natural Hazards, v. 49, no. 1, p. 53-77, doi: 10.1007/s11069-008 -9276-9.

Wechsler, N., Katz, O., Dray, Y., Gonen, I., and Marco, S., 2009, Estimating location and size of historical earthquake by combining archaeology and geology in Umm-El-Qanatir, Dead Sea transform: Natural Hazards, v. 50, p. 27-43, doi: 10.1007/s11069-008-9315-6.

Manuscript AcCePted by the Society 19 May 2010 